\title{
Positive and Negative Politeness Strategies Used by Kenya's Members of National Assembly
}

\author{
Emmanuel Njuki ${ }^{1}$, Humphrey Kirimi Ireri² \\ ${ }^{1}$ Kanjoo Secondary School, Maua, Kenya \\ ${ }^{2}$ Chuka University, Chuka, Kenya \\ Email: Emmanuelnjuki12@gmail.com,irerih@yahoo.com
}

How to cite this paper: Njuki, E. and Ireri, H.K. (2021) Positive and Negative Politeness Strategies Used by Kenya's Members of National Assembly. Open Access Library Journal, 8: e7690.

https://doi.org/10.4236/oalib.1107690

Received: June 24, 2021

Accepted: August 24, 2021

Published: August 27, 2021

Copyright () 2021 by author(s) and Open Access Library Inc.

This work is licensed under the Creative Commons Attribution International License (CC BY 4.0).

http://creativecommons.org/licenses/by/4.0/ (c) (i) Open Access

\begin{abstract}
Linguistic politeness enhances proper interaction among members of the society. During social interactions, interlocutors try to protect their positive public self-image and want to be seen as valuable members of the society. Politeness ensures effective Linguistic politeness enhances proper interaction among members of the National Assembly as they interact with each other in parliament. This study focused on the speeches of selected Members of Parliament in parliament context in order to find the positive and negative politeness strategies that they use. The researcher used politeness theory by Brown and Levinson (1987) to analyze, interpret and discuss the data collected. The data was downloaded from the Hansard and analyzed using content analysis method. This paper used purposive sampling technique where only the utterances with positive and negative politeness strategies were selected for inclusion in this paper. Descriptive qualitative research technique was used in the analysis of data. A guiding card was used to identify positive and negative politeness strategies. This research found out that members of National Assembly use positive and negative politeness strategies to lessen threats to face. The findings of this study will add to the existing literature in the field of sociolinguistics and pragmatics. They will also help interlocutors understand strategies that they can use in order to communicate effectively so that both parties feel appreciated in a conversation.
\end{abstract}

\section{Subject Areas}

Linguistics

\section{Keywords}

Politeness, Strategies, Face Threatening, Face Saving, Interlocuters, Parliament 


\section{Introduction}

Politeness strategies are utilized by interlocutors to reduce the effects of face threats. Brown \& Levinson (1987) [1] provide four politeness strategies that are used in interactions to reduce friction in talk. (Brown, 1970) [2] ascertain that these strategies are used to formulate messages in order to save the hearer's face when face threatening acts (FTAs) are desired or are unavoidable. Bald on record is applied where an act is stated clearly, concisely and directly. This is the least polite strategy as it involves stating something as it is without caring about the hearer's face. A positive politeness strategy seeks to minimize threat to hearer's positive face and make the hearer feel good about him/herself. A negative politeness strategy is avoidance based and it presumes that the speaker will be imposing on the hearer. Off record strategy uses indirect language and removes the speaker from the potential to be imposing on the hearer. Watts (2003) [3] argues that directly stated utterances such as criticizing may curb addressee's freedom of choice of action.

Yusti (2013) [4] observes that a conversation is determined to develop a social relationship. She argues that communication is more than information exchange because through conversation, it can be decided whether the message is received by the hearer or not. Conversation is influenced by politeness strategies because the content in the talk goal of politeness is to make all parties relax and feel comfortable with each other. Yusti's study mainly focuses on the politeness strategies used by an interviewer during an interview with Barack Obama, who was the president of the United States of America and therefore had a higher rank than the interviewer in terms of status. Unlike the current study, Yusti (2013) [4] considers sociological variables of politeness and how they influence choice of politeness strategies.

Barbora (2013) [5] finds that female discourse is politer than male discourse. It also found out that gender's style of speech is more or less equal in certain circumstances and gender roles are still far from equal in daily life. Barbora (2013) [5] claims that if gender roles were on an identical level, females would not tend to use politer expressions. Dissimilar from this study, Barbora (2013) [5] concentrates on language use and gender and how males and females differ in use of politeness. This study analyzed characteristics of language use in parliament without concentrating on gender differences.

Mag (2015) [6], finds out that online gamers use several politeness strategies and other stylistic features to communicate with fellow online gamers. He found out that gamers expressed themselves using acronyms and smileys. He concluded that the stylistic features used by gamers are an expression of creativity. Gamers use politeness since it gets them better responses. They become friendly to gamers who are friendly to them and impolite to those who are unfriendly to them. Mag (2015) [6] also noted that the use of politeness depended on the character the gamers were playing. This study took a different approach from Mag (2015) [6] and also explained the face threatening acts that destroy face of inter- 
locutors during social interaction.

Bengsch (2010) [7] highlights the importance of courtesy for front line staff. He states that verbal and non-verbal communication channels are used by customers to facilitate polite communication. Both channels are important to employees and non-negotiable for the interactions. The goal in a request situation is to provide a solution for the guest, which requires clear verbal messages to ensure that the guest feels understood and the request is being validated and clear nonverbal messages to indicate an action or follow up by the staff members.

Harris (2001) [8] describes parliament as a "community of practice". This is because the members of parliament have a common interest and they are engaged mutually. This involves how they talk and carry themselves in public. They are in direct contact with each other. Good conduct is one of the aspects that cannot be separated from good leadership. Pizziconi (2006) [9] argues that politeness is rule controlled prospect of interaction with an aim of maintaining social cohesion and maintaining an individual's face. A good leader should be able to communicate effectively while minding about their addressee's face. He or she should speak to others in a way that abides by the expectations of courtesy of the parliament. People are judged by members of the society according to how they carry themselves around. Politeness can be seen as a matter of courtesy and common sense by the general public.

Politeness is very important during social interaction since people are judged according to how they talk. Politicians are role models and national leaders of the people and therefore it is vital that they attend to the face needs of their colleagues in order to communicate effectively. However, sometimes, politicians have been condemned for speaking without thinking about the impact and weight of what they are saying. When effective communication is not achieved, leaders may end up embarrassing themselves and creating a negative impact to the public. Studies have been conducted on politeness used in different contexts. Parliamentary studies have concentrated on other aspects such as language and power, language and gender and hate speech. A study on politeness strategies in parliamentary discourse is also necessary. This is the gap that this study intended to fill.

\section{Methodology}

The population of the study consisted of all the face threatening acts and politeness strategies used by parliamentarians in parliamentary debates. The sampling technique that was used in this study was purposive sampling. Data was collected for a period of five parliamentary sessions which provided adequate data for analysis. Extracts from the $12^{\text {th }}$ parliament proceedings were retrieved from Hansard and then content analysis of the speeches was done in order to identify relevant excerpts that contained politeness strategies. Regarding ethical considerations this research used data from the Hansard which is in the public domain and so no pseudonyms were used to conceal anonymity. 


\section{Positive and Negative Politeness Strategies Used by Kenya's Members of National Assembly}

\subsection{Positive Politeness Strategies}

Brown \& Levinson (1987) [1] outline the following positive politeness strategies: claim a common ground, give/ask reasons, include speaker and hearer in the activity, intensify hearer's interest, give gifts to hearer, be optimistic, use in-group identity markers, joke, seek agreements, offer/promise, notice and attend to hearer's interests and needs and presuppose. The following strategies were identified in MPs speech.

\subsubsection{Claim Common Ground}

Claiming a common ground shows a speaker's and hearer's friendship and their interest with each other. This is achieved through the use of small talk. The speaker talks for a while about an unrelated topic before focussing on the main agenda. Claiming a common ground shows that the speaker acknowledges the hearer. Members of parliament claim common ground by engaging in small talk in order to reduce effects of a FTA towards the addressee.

\section{PST 1}

Hon. Speaker: Next is Hon. Wanyonyi, member for Kwanza.

Hon. Ferdinald Wanyonyi: Thank you Mr. speaker. Last weekend I went to a funeral and two ex-MPs tried to greet me yet I did not know who they are. I asked myself what mistake I did to be an MP. They looked pale and worn-out. ... I support this bill and I will amend it to have additional money. Thank you.

Before Hon. Wanyonyi narrows down to give his opinions about the current motion, he engages the members in a small talk. This helps him claim a common ground by telling his colleague MPs of the experience he saw when he met two ex-MPs who have become desperate due to poverty. The aim of this small talk is to convince MPs to support a bill that intends to pay ex-MPs Ksh. 100,000 each per month for their upkeep. To avoid directly imposing his interest on his colleagues, he claims a common ground through small talk. This lessens the potential threat to their face.

\section{PST 2}

Hon. George Gitonga: Madam speaker this country is suffering. Sorry deputy speaker. I had not looked up... I mentored him in form one and now see where he is.

Deputy Speaker: It is okay Hon. Gitonga. He was a captain at Kabarak High. He was kind to us Monos. I still learn from him. Proceed.

Hon. Gitonga misidentifies the deputy speaker by using the wrong address term, "madam speaker". This threatens his face. In order to restore face, they engage in small talk where Hon. Gitonga informs the house that he mentored the deputy speaker when he joined form one. The deputy speaker also informs the members that Hon. Gitonga was his school captain and he still learn a lot 
from him. This act of claiming a common ground is a politeness strategy used by a speaker to lessen a FTA.

\subsubsection{Give/Ask for Reasons}

This strategy is used when a speaker does not want to seem to impinge upon or does not care about the hearer. The speaker tries to explain why the hearer needs to do or avoid doing something. PSTs 3 and 4 explain this.

\section{PST 3}

Deputy Speaker: Let us have the "father of the house".

Hon. Jimmy Angwenyi: ...lets support this bill because one day in 2022, 2027 or in future, you will need it. It could be sooner because $70 \%$ of us will be kicked out in 2022 . The remaining ones will also be out during the next elections. Let us assist those ex-MPs who are still alive. We might prolong their lives.

To avoid looking like he is coercing his colleagues to pass a motion that is set to pay retired MPs Ksh. 100,000 every month, Hon. Angwenyi gives reasons why all MPs should embrace the motion and pass it. He reminds them that one day they will all be retired MPs and will need a source of income. In this case, Hon. Angwenyi wants all MPs to see the importance of the bill.

\section{PST 4}

Hon. Martin Owino: Hon. Speaker...

Deputy Speaker: Order Hon. Owino, I am not Hon. Speaker.

Hon. Martin Owino: I am so sorry; I was not looking up.

In PST 4, giving reasons as a strategy is used as a form of apology to lessen the FTA caused by Hon. Owino after addressing the deputy speaker using the wrong address term. Owino apologizes and tells the deputy speaker the reason for using the wrong address term is because he had not looked up to notice the speaker had left the chair. This strategy helps restore addressee's face.

\subsubsection{Include Speaker and Hearer in the Activity}

The speaker uses this strategy to show a need for cooperation between interlocutors. To include speaker and hearer in the activity, the speaker uses an inclusive "we" pronoun when he means "me/ you". MPs use this strategy to show cooperation. Consider the PSTs below.

\section{PST 5}

Hon. Didmus Barasa: Mr. speaker protect me from this Gladys Wanga.

Hon. Speaker: You are protected.

(Hon. Passaris stands in her place)

Hon. Speaker: I will not allow disorder Hon. Passaris.

(Hon. Passaris walks towards the speaker)

Hon. Speaker: We cannot behave as if we are conducting public rallies in the house. Let us have dignity when we are here. 
The speaker uses the inclusive pronoun we to include all MPs warning them to conduct serious business in parliament. This statement however is addressed to Hon. Passaris who had caused commotion in the chambers by shouting and walking towards the speaker after being insulted by Hon. Barasa. The speaker avoids using "you" to refer directly to her hence he does not threaten her face. The speaker avoids telling Hon. Passaris "you cannot behave as if you are conducting public rallies in the house. You should have dignity when you are here". This utterance would have been a direct impingement on Hon. Passaris' face. Replacing "you" with “we” in PST 5 reduces the threat to Hon. Passaris's face. Therefore, the speaker displacing his/her target saves their face.

\section{PST 6}

Hon. Jimmy Angwenyi: Hon. Speaker, when we were sworn in, we swore to protect the constitution. Who can allow homosexuality to be discussed here where we were sworn in?

To show solidarity, Hon. Angwenyi uses inclusive "we" to include all MPs reminding them that the chambers must be respected and they should not allow delegates misuse the house by discussing matters of gaysm and lesbianism. Inclusive we in this case is a politeness strategy meant to request for cooperation from all members not to allow intruders use the house. Inclusive we in interaction confirms friendly relations between interlocutors. It shows that they are one group. Hon. Angwenyi in PST 6 suggests that all MPs must work in solidarity to stop delegates from using the parliament to discuss issues related to homosexuality.

\subsubsection{Intensify Interest to Hearer}

By using this politeness strategy, the speaker exaggerates the interest of the hearer in an activity. The strategy shows that the interlocutors have a mutual want. The hearer becomes interested in the story and therefore the potential threat that the act could cause is avoided or lessened. This is explained in PSTs 7, and 8 .

\section{PST 7}

Hon. Wilberforce Oundo: Thank you. This is a very important bill in view of the happenings of the country. Parents and spouses have lost their children and spouses in gambling and gaming. Cases have arisen of campus students losing their school fees to gambling... I urge all members to support this bill.

To convince the MPs to support the gaming bill, Hon. Oundo intensifies the interest of the story to the addressees for them to see the negative effects of betting. He tells his colleagues how parents and spouses are suffering because their loved ones have resulted to betting and playing casinos. Hon. Oundo intensifies MPs interest in the story by mentioning that the bill is "very important". Intensifying interest to the hearer lessens the FTA that would occur if the speaker 
stated the FTA directly without using intensity. This is a strategy to convince members pass a bill that will see betting firms reduced in the country.

\section{PST 8}

Hon. Jimmy Angwenyi: Thank you for allowing me to talk about this very important bill. It should have been brought here ten years ago. We could have benefitted when we got kicked out of parliament. We have experienced what one goes through as a former member of parliament.

Hon. Angwenyi intensifies the interest of his addressees by stating that the bill is so important that it should have been brought to parliament ten years ago. He also refers to the bill as "very important". He states that if the bill had been passed ten years ago, he would have benefitted by getting pension money when he was kicked out of parliament before he was re-elected. This makes the hearer interested and this convinces them to support it without feeling impinged upon.

\subsubsection{Give Gifts to Hearer}

Another politeness strategy used by MPs is giving gifts to the hearer. Brown \& Levinson (1987) [1] ascertain that gifts, in this case do not only refer to physical gifts, but also gifts of understanding, sympathy, cooperation an admiration.

\section{PST 9}

Deputy Speaker: Hon. Odhiambo you were slightly off the track but I am in a magnanimous mood this evening because Christmas is approaching.

Hon. Odhiambo takes the floor but instead of contributing to the motion, she goes out of topic. It is expected that the deputy speaker should stop her and warn her against going out of topic. The speaker however avoids reprimanding her and instead gifts her the gift of understanding thus saving her face. Understanding the actions of a speaker by the hearer saves his/her face that would be lost if the hearer would rebuke him/her. This is in line with the positive politeness strategy of giving the hearer a gift.

\section{PST 10}

Hon. Eve Obara: ...there were very few women in parliament and because of them, we have 47-woman representatives in addition to 23 elected female MPs. We should all open doors for those who will come after us.

Deputy Speaker: You have spoken straight to the speaker's heart.

The deputy speaker in PST 10 gives Hon. Obara the gift of cooperation whereby he supports her views that women MPs should work harder to open doors for those who will be elected in future to find parliament a better place. Such gifts make the hearer feel good about their positive face; the want to be admired. This politeness strategy therefore makes the hearer feel that their proposals are 
endorsed. It also strengthens the bond between the speaker and the addressee and satisfies some hearer's wants. Giving gifts to the hearer also makes them feel comfortable and shows approval of their legislation and ideas. For a better interaction between interlocutors therefore, they need to give each other gifts of good relation by satisfying hearer's wants.

\subsubsection{Be Optimistic}

The speaker uses this strategy expecting the best outcome possible from the addressee. The speaker presumes that his wants and the wants of the speaker are mutual and the addressee will cooperate with him. The speaker expects the hearer to react accordingly and respond positively.

\section{PST 11}

Hon. Aden Duale: Hon. speaker, can you tell the chair of BAC (Budget and Appropriation Committee) and the member for Kirinyaga that the way they are talking is not parliamentary. In fact, even how close they are... you know this is the National Assembly.

Hon. Duale is optimistic that the speaker will react accordingly and tell the two members talking to keep quiet. He is optimistic that the hearer will cooperate with him because it is for their mutual benefit since noise is disrupting proceedings. Hon. Duale risks losing his face in parliament if the speaker fails to show cooperation by taking action against the MPs who are acting unparliamentary. However, the speaker reacts positively by asking the members who were talking to maintain silence. Being optimistic is a strategy a speaker uses hoping the addressee will show cooperation since the wants of the speaker and hearer are mutual.

\section{PST 12}

Hon. Millie Odhiambo: I can see someone is complaining and trying to harass me that women MPs are not doing better than male MPs. Even looking at the Hansard proofs so.

Deputy Speaker: Hon. Millie, I know you can never be harassed. Not even by Hon. Nguchine who is seated across the aisle from you.

In PST 12, Hon. Odhiambo is optimistic that the deputy speaker will support her against male members who are complaining and trying to harass her when she says women MPs are far much better than men in parliament. The deputy speaker attends to her needs when he says he knows that she can never be harassed by anyone because she is bold. Brown \& Levinson (1987) [1] posit that this politeness strategy is used by the speaker expecting the best outcome possible. The speaker expects that the hearer will notice the need and cooperate with the speaker to attend to it. However, by using this strategy, the speaker risks losing his/her face in case the hearer fails to show addressee cooperation. By the speaker being optimistic that the hearer will show cooperation, he/she assumes that the hearer wants speaker's wants and he/she will help hearer obtain them. 


\subsubsection{In-Group Identity Markers}

Each group possesses its own identity markers that show a sense of belonging to a certain group. They are meant to show solidarity. Brown \& Levinson (1987) [1] ascertain that such markers help claim a common ground between interlocutors thus avoiding any threat that an utterance would have caused to face. MPs identify themselves using words such as "Hon. Members" "brothers and sisters" and "friends" to show solidarity with each other. Consider the following PSTs.

\section{PST 13}

Hon. Didmus Barasa: I want to urge my friends in this house to support the report.

\section{PST 14}

Hon. Jimmy Angwenyi: The ones (ex-MPs) I saw the other day are on a death row. My brothers and sisters, let us be sympathetic.

PST 15

Hon. Nicholas Mwale: I follow the speaker's ruling and not your ruling my brother.

In the above examples, several in-group identity markers have been used to ensure inclusivity of the speaker and the addressee. In PST 13, Hon. Barasa uses the word "friends" to refer to all MPs to show their close relationships. This is meant to urge all MPs to support the report as a group. Hon. Angwenyi, in PST 14 refers to the members as "brothers and sisters". This is a politeness strategy meant to convince members to pass the motion. In PST 15 Hon. Mwale uses in group marker "brother" to reduce the effect of the FTA caused to the addressee when he tells him that he can only follow speaker's order and not any other. MPs also refer to each other as honourable members as an in-group marker. In-group identity markers convey group membership. It can therefore be concluded that in-group identity markers are evident in MPs speeches that are meant to show solidarity and to convince addressees to support speaker's point of view.

\subsubsection{Joke}

Joke is used by interlocutors to put them at ease and as a comic effect to reduce the seriousness of a situation. As a politeness strategy, a joke is used to claim a neutral ground and lessen the seriousness of a FTA. A joke is based on shared values. PSTs 16 and 17 are good illustrations of this.

\section{PST 16}

Hon. Aden Duale: The BBI (Building Bridges Initiative) was released. Go and cry at home if you are a loser. When the acting prime minister is talking you keep quiet.

(laughter) 


\section{PST 17}

Hon. Chris Wamalwa: A good wife comes from God. I have never been beaten as you can see. So, I am not going to be put in a septic tank.

(laughter)

In PST 16, Hon. Duale threatens Hon. Washiali's face telling him to go and cry at home if he feels that he lost when BBI report was released. To lighten the seriousness of the FTA, he jokes about being an acting prime minister which leads to laughter. This joke is used as a positive politeness strategy to ease the situation in the house. Similarly, in PST 17, Hon. Chris Wamalwa uses joking politeness strategy to reject the issue of community profiling against women by some members. He states that he is married from a community where women are believed to beat and kill men. He uses the joke to pass a message that community profiling must end. Jokes therefore are politeness strategies used by members of parliament to decrease the effect of a FTA.

\subsubsection{Seek Agreements}

Another politeness strategy that MPs use in the National Assembly is seeking ways in which to agree with the addressee. Seeking agreement with the hearer makes the speaker achieve the desire of the hearer to be right and their opinion endorsed.

\section{PST 18}

Hon. Didmus Barasa: I apologise to Hon. Passaris and I withdraw the statement. I invite her for dinner at 7.30 in the evening.

Hon. Speaker: Hon. members, Hon. Barasa has complied. He has done exactly what he is supposed to do. He has complied.

Hon. Barasa insults Hon. Passaris (in PST 52) which leads to commotion. $\mathrm{He}$ apologises to her and even offers to buy her dinner so as to be forgiven. The speaker agrees with him that that was the right thing to do after wronging someone. This politeness strategy of seeking agreements satisfies hearer's positive face want to be liked and appreciated. The speaker seeks agreement as an effort to show politeness. Seeking agreement by the speaker makes the hearer feel comfortable. The hearer feels appreciated by the speaker. This strategy can also be used when the speaker wishes to withdraw any threats of imposition on the hearer. For instance, in PST 22, the other MPs insist than Hon. Barasa apologizes for insulting Hon. Passaris. The speaker saves his face by agreeing with him that he had done exactly what he was supposed to do. This act is used to lessen potential face threats to Hon. Barasa.

\section{PST 23}

Hon. Aden Duale: Mr speaker, I want to agree with you that we make parliament look bad in the public eyes. We must follow the constitution and perform our functions as it provides. 
Hon. Duale fulfils the speaker's desire for his actions to be endorsed by members by seeking agreement with him. The speaker notes that it is the MPs who make the house look bad in the public eyes. Through seeking agreements, the speaker shows solidarity with the hearer thus saving his face. This makes the hearer feel good about himself and his opinions. Hon. Duale shows his agreement with the speaker's ideas that it is the MPs who make the members of the public dislike them due to their bad conduct while in the house. Hon. Duale therefore satisfies the speaker's desire for his legislation and ideas to be endorsed by others. Therefore, showing agreement is a strategy used to make an addressee feel comfortable and it removes potential threats of imposition on the hearer.

\subsubsection{Offer/Promise}

Brown \& Levinson (1987) [1] state that this strategy aims at cooperation between interlocutors. When the hearer's face is threatened by a FTA, the speaker offers to do something for the addressee with an aim of restoring his/her face and bringing things back to normal. They ascertain that the speaker intends to satisfy addressee's positive face.

\section{PST 24}

Hon. Didmus Barasa: ...I apologise to Hon. Passaris and I withdraw the statement. I invite her for dinner in the evening.

Hon. Speaker: Hon. Members, Hon. Barasa has complied. He has done exactly what he is supposed to do. ...they seem to be smiling at each other.

After insulting Hon. Passaris calling her stupid, Hon. Barasa threatens her face. He decides to apologise. He offers to buy her supper in the evening as an apology to make her feel good hence positive politeness. An offer could also be a FTA since it also forces the hearer to either deny or accept them. Hon. Passaris in PST 24 may fail to accept the apology and the offer for dinner. This would embarrass Hon. Barasa thus a threat to his positive face. Brown \& Levinson (1987) [1] also state that accepting an offer forces a speaker to accept a debt. Hon. Passaris accepting Hon. Barasa's offer for dinner makes her indebted to go out for dinner with him. This therefore impinges upon her autonomy. However, in this case, this offer is a politeness strategy used to restore Hon. Passaris face after insulting her.

PST 25

(Hon. Jimmy Angwenyi stands)

Deputy speaker: I assure you that you will get a chance, but let us have Hon. Opiyo before you.

Hon. Angwenyi notices that the speaker has not noticed him after several attempts to get his permission to speak. This forces him to stand. The speaker promises to give him a chance to speak after Hon. Opiyo. This promise is used as a politeness strategy to save Hon. Angwenyi's positive face. The use of this 
strategy in PST 25 conveys cooperation between interlocutors. Deputy speaker's promise indebts him to a future action of fulfilling this promise. He would also threaten his own face if he fails to honour the promise. Brown \& Levinson (1987) [1] note that if the speaker is forced to make an offer unwillingly, he risks losing his face if the offer is not fulfilled. A speaker commits himself to a future action which violates his freedom of choice that should not break. MPs therefore give offers and promises to convey cooperation with the hearer and to show the speaker cares about the hearer. This strategy makes hearer feel good about himself.

\subsubsection{Notice, Attend to Hearer's Interests, Wants and Needs}

According to Brown \& Levinson (1987) [1] a speaker ought to notice something good about the hearer and show appreciation about it. This is a politeness strategy meant to make the hearer feel good about himself thus saving his face. PSTs 26 and 27 explain this.

\section{PST 26}

Hon. Speaker: I challenge my very good friend Hon. Kaluma to take this one up. I know you are very good in this area.

The speaker in the above PST makes a FTA towards Hon. Kaluma by giving him a task to propose amendments to parliament. This threatens Hon. Kaluma's face desire from being imposed upon. This act intrudes on Hon. Kaluma's personal space. The speaker lessens the effect of this FTA by noticing something good about Hon. Kaluma and tells him that he is very good in law. This makes him feel good about his prowess in law and this convinces him to take up the challenge. Noticing and praising hearer's achievements lessens the effect of a FTA since the hearer understands that he/she has been chosen to take up a task because he is good in it.

\section{PST 27}

Hon. Didmus Barasa: I support this report Hon. Speaker. It is a fair report done professionally. This committee is chaired by a person of high legal fraternity who understands the law.

Hon. Barasa attends to the face needs of the committee members in order to appreciate the good work they have done. He attends to their positive face to be admired by stating that they have done their work professionally and the chair of the committee is a very good lawyer. This is a politeness strategy of attending to the hearer by noticing and commenting about something good about the hearer. Therefore, it is evident from PST 26 and 27 that this politeness strategy makes interlocutors have a good rapport between them. Great rapport between a speaker and an addressee makes an addressee feel valued and would do something willingly without feeling pressured by the speaker. 


\subsection{Negative Politeness Strategies}

Negative politeness strategies include: be indirect, hedging, minimize imposition, be apologetic, give deference, impersonalize and using a general rule. Members of the National Assembly use several negative politeness strategies as discussed below.

\subsubsection{Be Indirect}

Brown \& Levinson (1987) [1] argue that the speaker should avoid impinging on the hearer's negative face by avoiding the assumption that the act involved in the utterance is also desired by the hearer. The speaker speaks in a way that avoids a direct request/command so that the hearer does not feel imposed on.

\section{PST 28}

Hon Speaker: I see members at the entrance. We want to start.

\section{PST 29}

Hon. Jacqueline Oduol: This is very important. As I support it however, I would have requested that perhaps we get clarity.

\section{PST 30}

Hon. Millie Odhiambo: What we see does not reflect what we have. Perhaps the house could look for ways we can fast track them.

In PST 28, the speaker requests the members to take their seats indirectly. This is to avoid imposing on their face. The speaker would inherently threaten hearer's face if he had directly told the MPs at the entrance to enter immediately and assume their seats. The speaker thus avoids a direct FTA and states his utterance indirectly. This indirect request acts as a politeness strategy to make MPs assume their seats.

Hon. Oduol in PST 29, passes the message that the bill is not clear indirectly. The phrase "this bill is not clear" would threaten the face of the committee members who proposed the bill. To avoid threatening the addressee's face, she first notes that it is very important. She then states that she supports it but there is need for clarity. Through her statement, she passes a message that the bill is good though it requires some clarity. This is a politeness strategy focussed on avoiding imposition to the hearer's face hence satisfying their needs.

Hon. Odhiambo in PST 30 becomes indirect while suggesting that the report does not reflect what is on the ground. The use of the words "perhaps" "would you kindly", "could you" and "may we" by the members of the National Assembly are strategies they use in order to make face threats towards the hearer less serious thus saving their face. Being indirect allows MPs to pass a message that would otherwise pose a threat to the addressee's face. Therefore, being indirect is 
a politeness strategy.

\subsubsection{Hedges/Questions}

This strategy makes use of non-committal statements that make the hearer feel that he/she is not coerced to do something. MPs use hedging devices such as use of the words "I wonder if", "could you", "it seems", and "I think" to make it clear that the speaker does not want to impose on the hearer but only giving their genuine opinions.

\section{PST 31}

Deputy Speaker: The thing that makes me wonder how this committee can suggest this is the title of this act. Competition. This is interesting.

\section{PST 32}

Hon. Sakwa Bunyasi: First, I wonder why this is under competition authority. It should be under arrangement for wholesaling and retailing.

\section{PST 33}

Hon. Kimani Ichung'wah: Although this is important, I think it is important for the movers to look for ways to focus on the right institution.

\section{PST 34}

Hon. Speaker: Hon Limo and Duale, could you put your heads together and make sure the amendments have the same effects?

Hedging as a politeness strategy is used in the above PSTs when speakers don't want to directly coerce the hearer to do something. This is a negative politeness strategy that is avoidance based to help save addressee's negative face want not to be imposed on and their right for autonomy. The deputy speaker in PST 31 suggests that the committee should change the title of the act but uses hedging to lessen the effects of the FTA. The same case is evident in PST 32. Hon. Ichung'wah, in PST 33 thinks that the movers need to focus on the right institution and to avoid imposing on the movers of the motion, he says, "I think it is important". The speaker also makes a request through hedging in PST 34 by asking Hon. Duale and Hon. Limo if they could cooperate. Therefore, hedging strategy is used to avoid possible face threats. For instance, in PST 33 Hon. Ichung'wah would threaten the face of the motion movers if he had stated his utterance as "the movers of this motion must look for ways to focus on the right institution". However, he avoids damaging their face by saying "I think it is important for..." thus making it sound as if the utterance is just a polite request. MPs therefore use hedges to tone down the weight of a request. They reduce the weight carried by an utterance. The use of questions as a politeness strategy helps to satisfy speaker's want of not assuming that the hearer is able or willing 
to do something. This is seen in PST 34 where, instead of the speaker telling Hon. Duale and Hon. Limo to focus on the right institution baldly, he states the utterance in form of a question which lessens its potential negative effect to face by saying, "could you put your hands together?" the speaker is avoiding offending the addressees since it shows that the speaker is not trying to impose his thoughts on the hearer. Instead, he makes it sound like a suggestion and thus shows respect to the addressee's face. All these instances show that the speakers are focussed on avoidance-based strategies through hedging, hence ensuring politeness.

\subsubsection{Minimise Imposition}

Minimizing the imposition as a politeness strategy intends to lessen the seriousness of the FTA towards the hearer. The speaker uses this strategy to suggest that it was not that serious and should be taken lightly by everyone. It shows that the extent of the imposition is not much. It is just small and should not be taken seriously.

PST 35

Hon. Kassait Kamket: According to Kenyans, ni kama huyu anakula kwa macho. Deputy Speaker: You know the standing orders clearly. Use English. Hon. Kassait Kamket: Sorry, I was just quoting.

Code mixing is prohibited in parliament. When Hon. Kamket mixes English and Swahili, the deputy speaker gives him a stern warning reminding him that standing orders prohibit mixing codes. To lessen the effect of the situation Hon. Kamket states that he was just quoting from Kenyans and nothing should be taken seriously. He also apologizes. This is the use of negative politeness strategy of minimizing imposition. The use of the word " just" understates the seriousness of the imposition.

PST 36

Hon. Simba Arati: The hatemongers always wish evil on a good person like me... If you ask Hon. Barasa, I did not touch him. We only said hi to each other.

Hon. Nguna informs the speaker that the police are looking for Hon. Simba everywhere after causing chaos in Kibra. Hon. Simba, in PST 36, minimizes the seriousness of this situation by telling the house that the issue is not that serious. He says they did not even touch each other, they only said hi to each other. This is meant to reduce the imposition so that the speaker does not inform the police or kick them out of the chambers. The choice of this politeness strategy therefore helps avoid the foreseen danger that may occur. It shows that the addressee should not take the action so seriously. However, this strategy is used when the speaker knows that an utterance will threaten hearer's face. The speaker tries to 
minimise the imposition of that FTA to make it less serious so that the addressee does not take it too seriously.

\subsubsection{Be Apologetic}

This is another politeness strategy used by members of the National Assembly. The speaker apologizes for impinging on hearer's face. Apologizing lessens the effect of the FTA that has been caused by the speaker to the addressee.

\section{PST 37}

Deputy Speaker: Hon. Oduol I am sorry to interrupt you but time has caught up with us.

\section{PST 38}

Hon. Marseline Arbelle: ...there was a pornographic clip that went viral...

Hon. Speaker: I am sorry; I will not allow that particular aspect to be a subject of debate.

By apologizing, a speaker shows politeness to the hearer. It reduces face threats. There are various ways a speaker shows apology. They include, giving reasons for doing a FTA, indicating reluctance in doing a FTA, asking for forgiveness and admitting the impingement. In PST 37, the speaker cuts short Hon. Oduol's speech because time has passed. To minimise this threat on his face, he apologises and admits having impinged on his face want. He then gives a reason as to why it was unavoidable. This is meant to make Hon. Oduol understand that the speaker had no other option but to cut short his speech. Apologizing ensures friendly interaction between interlocutors. In PST 38, the speaker is apologetic for cutting short Hon. Arbelle's speech. This comes as a result of him going out of topic and raising a sensitive issue in parliament. This apology is meant to lessen negative effects of the FTA. In this utterance, the speaker gives a reason that he cut short Hon. Arbelle's speech because of discussing issues not related to the current topic of discussion. Through apologizing, the speaker indicates that he/she would not want to encroach on hearer's positive face but it was due to unavoidable reasons. This politeness strategy makes the hearer feel he/she has not been impinged upon. Therefore, apologizing is a politeness strategy that makes the hearer understand why the speaker threatened his/her face. It shows that the speaker acknowledges the hearer and respects his face.

\subsubsection{Give Deference}

Giving deference refers to praising the hearer. Brown \& Levinson (1987) [1] refer to this as paying the hearer a positive face. This strategy is meant to make the addressee feel appreciated by the speaker. Through this strategy, the speaker can use down scaling compliments to reduce his self-importance to make the hearer seem more important. The use of apologies and use of honorifics also gives the hearer deference. PST 39 and 40 show instances of giving deference. 
Hon. Speaker: Sometimes, it is good to stay until $6.00 \mathrm{pm}$. The member for Kilgoris is still in the house today. I encourage him to be sitting closer so I can see him.

The speaker notices that for the first time, the MP for Kilgoris had stayed in the house until past $6.00 \mathrm{pm}$. He gives him deference through humbling himself and praising the addressee to make him feel good. This satisfies hearer's want to be noticed and praised. He states that for once, the MP for Kilgoris had stayed until the end of a session. Praising him would make him feel good and notice that he had done a commendable thing. This would probably make him stop leaving before parliamentary sessions are concluded. Praising an addressee therefore could be used to make him/her continue performing an act without feeling coerced to do so.

\section{PST 40}

Hon. Olago Aluoch: I kindly ask you to guide members how to handle the BBI report.

Hon. Speaker: You have raised a very interesting issue. Hon. Aluoch is a senior lawyer in this country.

The speaker gives deference to Hon. Aluoch praising him for requesting the speaker to guide the MPs on how to handle the BBI report during recess. The speaker states that Hon. Aluoch is a senior lawyer in the country hence praising him. Brown \& Levinson (1987) [1] state that the speaker humbles himself and gives praise to the hearer hence satisfying his face wants. In giving deference, a speaker notices something positive about the hearer and praises him/her thus making him/her feel good.

\subsubsection{Impersonalize Speaker and Hearer}

This strategy avoids addressing the target but instead, a speaker speaks like he/she is addressing someone else or giving a general message. Brown \& Levinson (1987) [1] argue that this strategy avoids use of pronoun I and you and instead the speaker uses "we" "it seems", "it would be" and use of indefinites. By using this strategy, a speaker makes an assumption that the hearer will get the message and understand the intention of such an utterance. PSTs 41 and 42 illustrate this.

\section{PST 41}

Hon. Owen Baya: ...I want to concur with my colleagues. We should not blankly empower the treasury to make decisions alone.

Hon. Baya impersonalizes the speaker and hearer by using an inclusive "we" to give a conflicting opinion against his colleagues. He puts the FTA as if the addressee is not those MPs with conflicting opinions alone but everyone including 
the speaker. Impersonalization disassociates a hearer from a particular infringement. For instance, in PST 41, Hon. Baya avoids mentioning MPs who are blankly empowering the treasury to make all decisions alone. He instead uses " $w e$ " thus also including himself in the act. This is a politeness strategy meant to avoid threatening the addressee's face.

\section{PST 42}

Hon. Alandi: Hon. Speaker, Moses Kuria added my name to the committee without consulting me. It will be important for anyone who forms a committee to engage members before including them.

While rejecting the appointment in the committee, Hon. Alandi uses passive voice "it will be important for anyone..." to impersonalize the speaker and hearer. This is meant to avoid directly rejecting Hon. Kuria's appointment. This strategy therefore addresses the target indirectly by making the FTA look like a general message to everyone/someone else. The use of the word "anyone" in PST 42 avoids direct reference to the addressee who is Hon. Kuria. Impersonalization can be used as a sign of respect to avoid damaging the target's face. It also refers to other members of parliament and thus the statement also passes Hon. Alandi's message in the house.

\subsubsection{Using a General Rule}

Using a general rule is a politeness strategy meant to disassociate the interlocutors from an imposition of the FTA. This strategy avoids mentioning the addressee and instead gives a general message that applies to what the hearer is doing.

\section{PST 43}

Hon. Speaker: Some of you are walking out because you have already finished your work for today. People do not find it easy to remain in the chamber.

While condemning the behaviour of some MPs coming to parliament and leaving after a while, the speaker uses a general rule by referring to "people" and "some of you". This is meant to disassociate target members from the FTA to avoid threatening his/her face. This strategy avoids mentioning names of the target addressee. His utterance is however addressed to the MPs who are walking out leaving the session ongoing. Avoiding mentioning the target's name saves their face. This is applied by using a general rule that could apply to everyone present.

\section{PST 44}

Hon. Speaker: Order members! Members of the $12^{\text {th }}$ parliament need another induction workshop to train them how to conduct business. You should laugh controllably. You are not crackling in the village. 
While addressing the disorderly members, the speaker uses a general rule stating that the members of the $12^{\text {th }}$ parliament need another induction workshop. This is a politeness strategy to avoid imposing on the target members. The speaker does not directly mention the names of the target MPs who are laughing uncontrollably and causing disturbance. He uses a general rule that means all members of the $12^{\text {th }}$ parliament need another induction. However, not all members are being unparliamentary. This therefore is a general message. This strategy removes the speaker from the position to be imposing on his target addressee thus saving his/her face. A general rule is inclusive and applies to everyone including the speaker.

\section{Conclusions}

This paper found out that Members of the National Assembly use positive and negative politeness strategies during their interaction in the August house in order to save their Face and their addressee's face. Politeness strategies are used by MPs to lessen effects of FTAs on interlocutor's face. The uses of positive and negative politeness strategies by MPs create solidarity and show that a speaker values the hearer's face wants. MPs make use of these politeness strategies to mitigate face threats. Table 1 below shows the frequency of positive and negative PSTs that were identified by the researcher in this study.

Table 1. Summary of PSTs used by members of the national assembly.

\begin{tabular}{ccc}
\hline Politeness Strategy & Occurrence & Percentage \\
\hline Positive politeness strategy & 39 & 43.3 \\
Negative politeness strategy & 17 & 18.8 \\
Bald on record & 21 & 23.33 \\
Off record & 13 & 14.4 \\
Total & 90 & 100
\end{tabular}

Positive politeness strategies were the most commonly used politeness strategy by members of the National Assembly. Thirty-nine occurrences of positive PSTs were identified by the researcher which contributed to seventy percent. This shows that MPs value their colleague's desire for appreciation and engagement. Positive politeness strategies occurred in form of claiming a common ground, giving/asking for reasons, including speaker and hearer in the activity, intensifying interest to hearer, giving gifts to hearer, being optimistic, using in-group identity markers, jokes, seeking agreements, giving offers and attending to hearer's interests and needs.

Negative politeness strategy was also used by MPs. It occurred in form of being apologetic, giving deference, impersonalizing, using general rules, minimizing imposition, hedging and being indirect. Negative PSTs occurred seventeen times which was eighteen percent of the total PSTs identified. This strategy satis- 
fied hearer's want not to be impended and has his actions untampered with.

Positive politeness strategy is used when MPs want to lessen threat to hearer's positive face. MPs use negative politeness strategy when they avoid impinging on hearer's negative face wants.

\section{Conflicts of Interest}

The authors declare no conflicts of interest.

\section{References}

[1] Brown, P. and Levinson, S. (1987) Politeness: Some Universals in Language Usage. Cambridge University Press, Cambridge.

[2] Brown, P. (1970) Face Saving Following Experimentally Induced Embarrassment. Journal of Experimental Social Psychology, 6, 255-271

[3] Watts, R. (2003) Politeness. Cambridge, Cambridge University Press.

[4] Yusti, Y. (2013) Politeness Strategies Used in the Exclusive Interview between Putra and Barrack Obama. M.A Thesis, Dian Nuswantoro University, Semarang: Indonesia.

[5] Barbora, S. (2013) Gender and Politeness in Discourse. M.A Research, Tomas Bata University, Masaryk, Czech Republic.

[6] Kramer, B. (2013) GTFO!! Politeness and Stylistic Features as Means of Positioning in MMORPGs (Massive Multiplayer Online Role-Playing Games). https://uscholar.univie.ac.at/detail/o:313572

[7] Bengsch, G. (2010) The Influence of Culture on the Perception of Politeness. United Research Bank, United New Zealand.

[8] Harris, S. (2001) Being Politically Impolite: Extending Politeness Theory to Adversarial Political Discourse. Discourse and Society, 12, 450-470.

[9] Pizziconi, B. (2006) Politeness. In: Mey, J.L., Ed., Concise Encyclopedia of Pragmatics, Elsevier, London. 